\section{Progress in Seismology}

THE forty-first report of the British Association Cornmittee on Seismological Investigations includes many points of interest. A brass sphere, 18 inches in diameter, has been made by Messrs. Casella for use in the determination of epicentral distances. The positions of observatories are marked by holes and the sphere has been chromium-plated. The Committee is indebted to Mrs. H. H. Turner for providing most of the accessories that will be used in ascertaining the distances and azimuths of the epicentres. Four small earthquakes were felt in the British Isles since the last report was presented, in the Channel Islands and at Leigh, Comrie and Kinlochewe. The earthquakes in the island of Montserrat continue, though they were less frequent during the first half of 1936 than in the two preceding years. A Wiechert horizontal seismograph has been installed, in addition to a number of Jaggar shock-recorders that were made at Kow Observatory for the use of the expedition sent out by the Royal Society. The preparation of the International Seismological Summary for 1931 has been completed, and the sections for the first half of the year have been printed and distributed. The number of earthquakes included is 297. References are also made to Dr. H. Jeffreys' revised table of transmission times recently published by the Bureau Central de Séismologie, to the unusually long seismic waves associated with the South Pacific earthquake of June 26, 1924, and to the Baffin's Bay earthquake of November 20, 1933.

\section{Megalithic Monuments of South Wales}

THE latest addition to the Megalithic Survey of England and Wales ("Map of South Wales showing the Distribution of Long Barrows and Megaliths". Compiled by F. W. Grimes. Southampton : Ordnance Survey. Pp. 56 and Map : Scale 4 miles to 1 inch. 58., 58. $6 d$. and $6 s .6 d$. net) incorporates the results of a survey of the area covered by Sheet 7 of the Quarter-inch Ordnance Map. It is now possible for the first time, as the Director-General points out in an introductory note, to assess the distribution of the megalithic monuments of an area which has been recognized as an important centre of the culture. This region, predominantly upland, and, therefore, differing essentially from others already covered by the series, falls into two parts, a narrow coastal plain of undulating country, seldom more than $400 \mathrm{ft}$. above sea-level, in which the monuments are mainly found, and an upland, which attains its greatest heights in Brecknock Beacons, and of which a large part is above the $1,000 \mathrm{ft}$. contour line. Mr. Grimes discusses a number of questions arising out of the distribution of the monuments, not the least interesting being those relating to his omissions, a matter with which he proposes to deal at greater length elsewhere. He also raises a question of wide general interest in connexion with Stonehenge. One of the most noteworthy contributions to British archæology of the post-War years was the conclusion, at which the late Mr. H. H. Thomas of the Geological Survey arrived in 1923, that the blue stones of the inner circle at Stonehenge were igneous rock derived from the Presely Mountains and the altar stone micaceous sandstone of either the Cosheston Beds around the estuary of Milford Haven, or the Senni Beds of Carmarthen and Brecknock; but up to the present no satisfactory hypothesis as to the method of transport and route has been offered. Mr. Grimes discusses the question in the light of his survey and gives his reasons for suggesting a route by both land and water in which transport from the Presely Mountains to the sea was effected by one of three possible ancient roads which he shows.

\section{Aleutian Islands' Skull of Abnormal Size}

DR. Areß HRDLIČKA, it is reported by the Smithsonian Institution, Washington, D.C., in the course of excavations on the Aleutian Islands, has brought to light a skull of remarkable size. Its cubic capacity is said to be no less than 2,005 c.c. This is the second highest skull capacity recorded, the largest being that of Turgenev, the Russian novelist, whose skull has a capacity of 2,030 c.c. Skulls of known capacity ranking next are those of Daniel Webster, 2,000 c.c., Bismarck, 1,965 c.c., La Fontaine, 1,950 c.c., Beethoven, 1,750 c.c. and Kant, 1, 740 c.e. The enormous, but imperfect, South African Boskop skull, according to one estimate, has been rated at 1,950 c.c.; but a more conservative figure places it round about 1,700 c.c. Dr. Hrdlička's excavations on the Aleutian Islands, in the course of which the present find was made, are in continuation of a series of investigations of the archæology and physical anthropology of the present and former inhabitants of Alaska and the adjacent islands, upon which he has been engaged on behalf of the Smithsonian Institution for successive seasons during a number of years. His object is to elucidate the racial affinities and chronological succession of the early peoples who migrated from north-eastern Asia to populate America. On this problem, unfortunately, his latest discovery, apart from the probability that it is no more than an individual instance of abnormal development, would appear to throw no certain light, owing to the absence of the facial skeleton.

\section{Human History and Geographical Discovery}

IN his presidential address to the British Academy in July last (London : Oxford University Press. 1s. net) Mr. J. W. Mackail said that we are at the beginning of a new era of discovery and interpretation which is revolutionizing the whole aspect of human history. Civilizations of the past in every continent are yielding up more of their secrets. Byzantine history, art and institutions have emerged from comparative neglect to an important place in humane studies. The past ages of India, China and Japan and even Central Asia are revealing their significance. The greatnesses of Central and South America are taking their place in the panorama of the past, and undiscovered Africa and impenetrable Arabia no longer exist. But important as are the acquisition and tabulation of knowledge, the primary function of humanism is the appreciation, in the largest sense of the word, of the classies of art, music, philosophy, 